DOI: https://doi.org/10.32836/2521-666X/2020-69-21

УДК 336.71

\author{
Синюк А.O. \\ аспірант, \\ Університет митної справи та фрінансів
}

\title{
Sinyuk Alina
}

University of Customs and Finance

\section{МЕТОДИЧНІ ПІДХОДИ ДО ВИЗНАЧЕННЯ БІЗНЕС-МОДЕЛЕЙ БАНКІВ В УКРАЇНІ}

\section{METHODICAL APPROACHES TO DEFINING BUSINESS MODELS OF BANKS IN UKRAINE}

У статті розглянуто основні наукові підходи до визначення бізнес-моделей українських банків. Визначені основні спільні риси та недоліки існуючих методологій. Досліджена методика аналізу бізнес-моделей, яку розроблено Національним банком України в межах реалізації SREP-аналізу. Доведено необхідність розвитку та доповнення існуючих підходів до визначення бізнес-моделей банків з урахуванням основних структурно-функціональних характеристик банків. Запропоновано власний набір основних коефіцієнтів-індикаторів, які дають змогу детально відобразити структуру активів, зобов'язань, доходів та витрат, а також особливості роботи кожного банку протягом певного проміжку часу. Обгрунтовано переваги застосування нейронних мереж та самоорганізаційних карт Кохонена (СОК) для проведення кластеризації банківської системи України.

Ключові слова: банк, бізнес-модель, кластерний аналіз, нейронні мережі, самоорганізаційні карти Кохонена, ризик-профіль.

В статье рассмотрены основные научные подходы к определению бизнес-моделей украинских банков. Определены основные общие черты и недостатки существуюших методологий. Исследована методика анализа бизнес-моделей, которая разработана Национальным банком Украины в рамках реализаџии SREP-анализа. Доказана необходимость развития и дополнения существуюших подходов к определению бизнес-моделей банков с учетом основных структурно-функииональных характеристик банков. Предложен собственный набор основных коэффициентов-индикаторов, которые позволяют детально отобразить структуру активов, обязательств, доходов и расходов, а также особенности работы каждого банка в течение определенного промежутка времени. Обоснованы преимущества применения нейронных сетей и самоорганизуюшихся карт Кохонена (СОК) для проведения кластеризации банковской системь Украины.

Ключевые слова: банк, бизнес-модель, кластерный анализ, нейронные сети, самоорганизующиеся карты Кохонена, рискпрофиль.

Today, the SREP (Supervisory Review and Evaluation Process) analysis model has become very popular in Europe. All financial institutions (banks) are distributed within the framework of the SREP analysis, depending on their size, structure, internal organization, complexity and variety of activities. In today's conditions, the issue of defining business models of banks in Ukraine and the associated risk profile is still insufficiently studied. In addition, the NBU has not yet formed a clear interpretation of the very concept of the bank's business model. There is also no common approach among researchers on the factors and indicators that should be used to determine the business models of banks. The proposed methods are based on the financial statements of banks and use cluster analysis tools. However, the time interval of the study, the number of defining characteristics involved in clustering, as well as the number of cluster groups obtained are differ in each study, and the interpretation of the results is based on the subjective judgment of the author. But the correct analysis of the bank's business model creates conditions for an early assessment of the risks of viability and financial stability of the bank, identifying its main weaknesses and controlling them. The process of defining business models covers the entire banking system, involves the use of large arrays of financial information and requires the simultaneous consideration of a significant number of variables. In such circumstances, it is advisable to introduce a methodology for determining business models using neural networks, including self-organizing Kohonen maps, which will group banks so as to cover their main essential structural and functional characteristics, as well as risks within the banking system of Ukraine. Thus, it is advisable to apply a differentiated approach to assessing the financial state and financial steadiness of the bank, based not only on certain indicators of its activity, but also on risk analysis, the distribution of banking system into close to each other, relatively homogeneous groups, the identification of interconnections between them and forming a clear idea of the business model of the bank.

Key words: bank, business model, cluster analysis, neural networks, Kohonen self-organization maps, risk profile.

Постановка проблеми. 32018 року Національний банк України розпочав поетапний перехід до реалізації наглядових процедур, виходячи з оцінки ризиків, які супроводжують діяльність банків. Це знайшло своє відображення у запровадженні нових наглядових процедур, в основу яких було покладено проведення оцінки ризиків банків та якості управління ними, що отримало назву «risk-based approach». Слід звернути увагу, що в країнах Свропейського союзу запроваджен- ня ризик-орієнтованого підходу у банківському нагляді розпочалося ще з 2013 року та було втілено у Директиві 2013/36/CC (CRDIV) Свропейського Парламенту та Ради про доступ до діяльності кредитних організацій та пруденційний нагляд за діяльністю кредитних організацій та інвестиційних компаній, а пізніше й у Настановах Європейського банківського органу щодо єдиних процедур та методології процесу наглядових перевірок та оцінки (EBA/GL/2014/13). Ще у березні 
2017 року НБУ було представлено проект «Положення про організацію системи управління ризиками в банках України». У 2018 році Постановою Правління Національного банку України № 47 від 02.05.2018 року було внесено зміни у «Положення про організацію та проведення інспекційних перевірок» [1], які враховують настанови Європейського банківського органу щодо організації єдиної процедури та методології процесу наглядових перевірок та оцінки (SREP). Затвердження y червні 2018 року «Положення про організацію системи управління ризиками в банках України та банківських групах» (Постанова Правління НБУ № 64 від 11 червня 2018 року) [2] дозволило визначити основні цілі та принципи управління ризиками, встановити мінімальні вимоги щодо організації в банку та банківській групі комплексної, адекватної та ефективної системи управління ризиками на основі розроблення декларації схильності до ризиків, визначення загального розміру «ризик-апетиту», встановлення лімітів ризиків та визначення профілю-ризиків банку, виходячи з його бізнес-моделі.

Проте необхідно зазначити, що нині питання щодо визначення бізнес-моделей банків в Україні та пов'язаного із ними профілю ризику все ще не досить досліджене. Це ускладнюється й тим, що НБУ досі не сформовано чіткого тлумачення самого поняття бізнесмоделі банку. Серед науковців також відсутній єдиний підхід щодо факторів та показників, які мають бути застосовані для визначення бізнес-моделей банків. Все це зумовлює актуальність теми дослідження.

Аналіз останніх досліджень і публікацій. Серед вітчизняних дослідників, які досліджували питання оцінки та аналізу бізнес-моделей банків, слід виділити праці О.О. Любіч, Г.П. Бортнікова, Г.О. Панасенко, які дослідили бізнес-моделі державних банків України, в іншій роботі Г.П. Бортніков, Г.О. Панасенко також звернули увагу на визначення моделей бізнесу українських банків у залученні коштів клієнтів. В.І. Бура дослідила бізнес-моделі системно важливих банків в Україні, О.В. Бронін провів аналіз бізнес-моделей українських банків, що призвели до банкрутства. Н.М. Пантєлєєва розглянула інноваційні бізнес-моделі банків. В. Рашкован та Д. Покідін, Ю.І. Онищенко та Е.Л. Заяць, А.В. Деркаченко та Ю.С. Худолій, О.В. Литвинюк та М.О. Карпов, А.С. Стадник здійснили аналіз банківської системи України для того, щоб ідентифікувати основні бізнес-моделі існуючих банків. Також слід звернути увагу на праці О.П. Заруцької та Т.В. Васильєвої, в яких було закладено основу для оцінки фінансової стійкості банків, виходячи 3 їхніх сутнісних структурно-функціональних характеристик. Незважаючи на наявний науковий доробок, питання визначення бізнес-моделей банків залишається не досить обгрунтованим, крім цього, питання сутнісних структурно-функціональних характеристик банків, що впливають на формування бізнес-моделей, та їх взаємозв'язок із профілем ризику банків залишається не до кінця розкритим.
Метою статті $\epsilon$ дослідження основних методичних підходів до визначення бізнес-моделей банків в Україні, визначення їхніх спільних рис та основних недоліків, а також обгрунтування доцільності запровадження методології для визначення бізнес-моделей з використанням нейронних мереж, зокрема самоорганізаційних карт Кохонена, що дозволяє згрупувати банки таким чином, щоб охопити їхні основні сутнісні структурнофункціональні характеристики, а також ризики в межaх банківської системи України.

Виклад основного матеріалу. Визначення бізнесмоделей банків складно віднести до простого завдання через наявність багатогранної та мінливої кількості даних, які характеризують роботу банку та його положення на ринку, великий ступінь залежності від деталізації даних, а також постійний вплив ризиків та різноманітних факторів внутрішнього та зовнішнього середовища. Науковці, як правило, віддають перевагу загальнодоступним даним, що зумовлено значним обсягом як показників для аналізу, так і самих банків. Як наслідок, отримується певна вибірка основних змінних, що будуть використані в аналізі, за певний проміжок часу, тобто масив даних. Дослідники, базуючись на своєму власному суб'єктивному судженні, вибирають методи роботи $з$ такими масивами та подальшої інтерпретації отриманих результатів.

Розглянемо основні існуючі підходи до визначення бізнес-моделей банків в Україні.

Ю.І. Онищенко [3] здійснила дослідження 131 українського банку станом на 01.01.2015 р. Для визначення бізнес-модель були використані такі сім основних показників:

1. Банківські позики (у \% від активів).

2. Банківські зобов’язання (у \% від активів).

3. Кредити юридичним особам (у \% від активів).

4. Зобов'язання перед юридичними особами (у \% від активів).

5. Кредити фізичним особам (у \% від активів).

6. Зобов'язання перед фізичними особами (у \% від активів).

7. Торгові активи (у \% від активів).

Проведений кластерний аналіз дав змогу виокремити три основні бізнес-моделі банків, такі як:

1. Роздрібно-орієнтована модель бізнесу, характерними для якої стали значний обсяг кредитів юридичними особам та значна залежність від стабільних джерел фінансування, в т.ч. депозитів, які займають приблизно дві третини у загальному обсязі зобов'язань середнього банку цієї групи. До складу цього кластеру потрапила найбільша кількість банків з усієї вибірки.

2. Диверсифікована модель бізнесу, характерним для якої стала відсутність переваги якогось одного певного напряму діяльності, оскільки банки, що потрапили у цю групу, використовують різноманітні джерела залучення та розміщення коштів, тобто характер їхньої діяльності можна визначити як універсальний.

3. Корпоративна модель бізнесу, характерним для якої стало обслуговування корпоративного сектору 
економіки, тобто кошти залучаються й надаються юридичним особам, крім цього наявний й інвестиційний портфель.

У іншому дослідженні, яке Ю.І. Онищенко провела разом із Е.Л. Заяць [4], було проаналізовано 84 українські банки станом на 01.01.2018 р. Основними змінними для проведення дослідження було вибрано такі:

1. Надані міжбанківські кредити (у \% від активів).

2. Кредити, що надані юридичним особам (у \% від активів).

3. Кредити, що надані фізичним особам (у \% від активів).

4. Інвестиційний портфель (у \% від активів).

5. Депозити, залучені від юридичних осіб (у \% від активів).

6. Депозити, залучені від фізичних осіб (у \% від активів).

Також, використовуючи інструменти кластерного аналізу, науковці сформували п'ять кластерів, кожний 3 яких характеризує відповідну модель бізнесу банків:

1. Перший кластер - традиційна бізнес-модель. У якості основних характеристик кластеру дослідники встановили: залучення грошових коштів переважно від фізичних та частково від юридичних осіб, а також кредитування корпоративного бізнесу.

2. Другий кластер - корпоративна бізнес-модель. У якості основних характеристик кластеру дослідники встановили: залучення грошових коштів переважно від юридичних осіб та частково від фізичних осіб, кредитування корпоративного бізнесу, значний обсяг інвестиційної діяльності.

3. Третій кластер - роздрібна бізнес-модель. У якості основних характеристик кластеру дослідники встановили: залученні грошових коштів від фізичних осіб та кредитування переважно фізичних осіб, що свідчить про високий рівень кредитного ризику для цього кластеру.

4. Четвертий кластер - універсальна бізнес-модель. У якості основних характеристик кластеру дослідники встановили: залучені та розміщені кошти диверсифіковані, грошові кошти залучаються від фізичних та юридичних осіб, кредити переважно надаються корпоративному сегменту бізнесу, проте присутнє кредитування й фізичних осіб, частина коштів також розміщена у інвестиційному та міжбанківському портфелі.

5. П'ятий кластер - інвестиційна бізнес-модель. У якості основних характеристик кластеру дослідники встановили: наявність значного обсягу інвестиційного портфелю, який складається в основному з облігацій внутрішньої державної позики, та залучення коштів від юридичних осіб.

Розгляд результатів, отриманих авторами цього підходу, свідчить про те, що не всі банки із сформованих груп є однорідними, з точки зору головних ризиків, які супроводжують сучасний етап розвитку банківської системи. Також, автори не враховують частку операцій банків в іноземній валюті, що суттєво впливає на характеристики активів і пасивів банків. Крім цього, у якості основних змінних для визначення бізнес-моделей обрані лише показники зі структури активів та зобов'язань банків, що не є вичерпним відображенням основних сутнісних характеристик банків.

Для визначення бізнес-моделей науковці А.В. Деркаченко та Ю.С. Худолій [5] проаналізували 93 українські банки станом на 01.01.2017 р. Дослідниками запропоновано систему з 12 показників, на основі яких було проведено кластеризацію банків:

1. Співвідношення активів банку до кількості філій, що дозволяє визначити ступінь інтенсивності використання філіальної мережі у діяльності.

2. Частка власного капіталу i субординованого боргу для визначення обсягу коштів, що запозичені банком.

3. Частка роздрібних (фізичним особам) кредитів у активах, які приносять дохід.

4. Частка роздрібних (фізичним особам) депозитів у загальних зобов'язаннях (без врахування субординованого боргу).

5. Частка роздрібних та корпоративних кредитів у активах.

6. Співвідношення між наданими кредитами та залученими депозитами (оптимальне значення не менше $70 \%)$.

7. Адекватність (достатність) капіталу банку, тобто спроможність в повному обсязі та у встановлений строк розрахуватися за всіма видами своїх зобов'язань.

8. Ліквідність банку, тобто спроможність забезпечити виконання своїх поточних зобов'язань протягом одного операційного дня за допомогою мінімального обсягу активів із найвищою ліквідністю.

9. Співвідношення між обсягом чистого процентного доходу банку та середньою сумою активів, на які нараховується процентний дохід (процентна маржа банку).

10. Співвідношення між резервами за кредитними операціями та загальним обсягом наданих кредитів, тобто рівень якості кредитного портфеля банку.

11. Рентабельність активів банку (ROA) для визначення ефективності використання банківських ресурсів.

12. Рентабельність капіталу банку (ROE) для визначення обсягу чистого прибутку, який приносить кожна гривня капіталу банку.

А.В. Деркаченко та Ю.С. Худолій виокремили п'ять бізнес-моделей українських банків, які ранжували відповідно до рівня їхньої фінансової стійкості:

1. Банки з високим рівнем фінансової стійкості, які відрізняються великою часткою депозитів від фізичних осіб, великою часткою кредитів, що надані також фізичним особам, значним рівнем розвитку філіальної мережі, оптимальним рівнем співвідношення між наданими кредитами та залученими депозитами, значним обсягом резервів за кредитними операціями, а також досить високими показники рентабельності активів та капіталу. На думку авторів методики, така модель $є$ найменш схильною до ризиків. 
2. Банки $з$ достатнім рівнем фінансової стійкості, які відрізняються значною часткою кредитів фізичним та юридичним особам, значною часткою депозитів, що залучені від фізичних осіб (але, менше ніж у банків першої групи), наявністю некредитних (торгових та ін.) активів, а також середнім рівнем процентної маржі, рентабельності активів та капіталу. На думку авторів методики, для такої моделі характерними є кредитний ризик та ризик прибутковості.

3. Банки з середнім рівнем фінансової стійкості, які відрізняються незначною часткою кредитів та депозитів фізичних осіб, основні ж операції проводяться 3 юридичними особами (як правило, короткострокове фінансування), а також незначним рівнем розвитку мережі філіалів. На думку авторів методики, для такої бізнес-моделі характерними $є$ ризики кредитування пов'язаних осіб, ризик ліквідності та відмивання коштів.

4. Банки із задовільним рівнем фінансової стійкості, які відрізняються значними обсягами власного капіталу та субординованого боргу, значними обсягами кредитів та депозитів фізичних осіб, показник співвідношення між розміщеними та залученими коштами неоптимальний. На думку авторів методики, для такої бізнес-моделі характерні ризики кредитування пов'язаних осіб, ризик концентрації, ліквідності та прибутковості.

5. Банки з низьким рівнем фінансової стійкості, які відрізняються значними обсягами власного капіталу та субординованого боргу та відсутністю залучених ресурсів у вигляді депозитів. На думку авторів методики, для такої бізнес-моделі характерні всі ризики, які наявні у банківській системі.

На нашу думку, запропонований авторами методики перелік змінних не охоплює некредитні операції банків, структуру доходів та витрат і валютні ризики банків. Крім цього, розподіл за рівнями фінансової стійкості є досить умовним, оскільки не враховує обрану банком модель бізнесу, для якої такі результати можуть бути характерними та природними.

Наступна група науковців (ОО. Любіч, Г.П. Бортніков та Г.О. Панасенко [6]) провела дослідження бізнесмоделей виключно державних банків в Україні. Для розподілу банків за бізнес-моделями була сформована така система показників:

1. Структура активів і зобов'язань за сегментами бізнесу:

- абсолютна сума (у млн грн.) активів та зобов'язань державних банків в розрізі корпоративного, роздрібного та казначейського бізнесу, а також їхня частка (у \%) в загальному підсумку;

- частка доходу на активи (у \%) корпоративного, роздрібного та казначейського бізнесу.

2. Структура доходів і витрат за сегментами бізнесу:

- абсолютна сума (у млн. грн.) доходів (в т.ч., процентних та комісійних), витрат (в т.ч., процентних та операційних), фінансового результату (різниця між доходами та витратами) в розрізі корпоративного, роз- дрібного та казначейського бізнесу, а також їхня частка (у \%) в загальному підсумку.

3. Показники ефективності діяльності (динаміка персоналу та активів):

- кількість персоналу (в особах) та його зміна з початку року;

- активи (у тис. грн.) та їх зміна з початку року;

- активи на одного працівника (у тис. грн.) та їх зміна $з$ початку року.

4. Відношення операційних витрат до операційного доходу (показник ефективності):

- операційні витрати (у тис. грн.);

- операційні доходи (у тис. грн.);

- співвідношення операційних витрат та операційних доходів (у \%).

5. Розподіл за показниками ефективності витрат i рентабельності активів:

- ефективності витрат (у \%);

- рентабельність активів (у \%).

6. Масштаби бізнесу:

- активи на одного працівника (у млн. грн.);

- операційний дохід на одного працівника (у млн. грн.);

- операційні витрати на активи (у \%).

7. Структура доходів

- частка процентних доходів у загальних доходах $(\mathrm{y} \%)$

- частка комісійного доходу в загальному доході (у \%);

- частка доходів або втрат від курсової різниці (у \%);

- частка доходів банку від переоцінки інвестицій (у \%);

- частка доходів банку від чистої зміни резервів (у \%).

8. Частка в доходах вибірки 30 банків за ключовими статями (у \%):

- процентні та комісійні доходи;

- надходження від: продажу цінних паперів, операцій із іноземною валютою, переоцінки іноземної валюти, переоцінки інструментів, розформування резервів та середнє значення зазначених показників по вибірці.

9. Стратегічні цільові сегменти клієнтури:

- продукти з кредитним та/або ринковим ризиками;

- інші банківські продукти.

10. Ставки залучення ресурсів:

- розмір ставок залучення ресурсів від населення в державних банках;

- розмір ринкових ставок.

11. Умови емісії єврооблігацій:

- найменування кредитора;

- сума (у млн дол. США);

- процентна ставка (у \%) до реструктуризації та після реструктуризації;

- строки погашення (у роках) до реструктуризації та після реструктуризації.

12. Кредитні рейтинги (довгостроковий рейтинг дефолту емітента в іноземній валюті):

- найменування рейтингового агентства;

- рейтинг.

Проведений аналіз згідно із зазначеною методикою вказав іiі авторам на універсальність бізнес-моделей державних банків із наявністю певної зосередженості 
на корпоративному сегменті переважно агропромислового комплексу, енергетики, енергозбереження та екології. На думку зазначених авторів, бізнес-модель державних банків має відображатися у їх спеціалізації на реалізації відповідних національних програм.

В іншій роботі Г.П. Бортніков [7] також розглянув бізнес-моделі українських державних банків. При цьому сформована науковцем система показників відрізняється від попереднього дослідження:

1. Розподіл доходів і витрат державних банків за сегментами бізнесу (корпоративного бізнесу, роздрібного бізнесу, казначейства, системи загального управління):

- структура доходів (у \%);

- структура витрат (у \%);

- різниця між доходами та витратами (у млрд. грн.).

2. Прибутковість активів державних банків за сегментами бізнесу:

- прибутковість активів (у \%) корпоративного бізнесу, роздрібного бізнесу, казначейства, системи загального управління.

3. Розподіл активів і зобов'язань державних банків за сегментами бізнесу (корпоративного бізнесу, роздрібного бізнесу, казначейства, системи загального управління):

- структура активів (у \%);

- структура зобов'язань (у \%).

4. Структура процентних доходів і процентних витрат державних банків у порівнянні з вибіркою банків (банки іноземних банківських груп, банки 3 приватним капіталом) та банківською системою загалом:

- частка в процентних доходах (у \%) доходів за кредитами юридичним особам та за кредитами фізичним особам;

- частка в процентних витратах (у \%) за залученими коштами юридичних осіб та фізичних осіб.

5. Структура кредитних портфелів вибірки банків:

- частка в загальних активах банку (у \%) кредитів юридичним та фізичним особам;

- частка кредитного портфеля в активах банку (у \%).

6. Структура кредитів фізичним особам за класами кредитного ризику (у \% за класами кредитного ризику від 1 д 5).

7. Структура кредитів юридичним особам за класами кредитного ризику (у \% за класами кредитного ризику від 1 до 10).

8. Кредити державних банків порівняно з вибіркою банків та банківською системою загалом:

- частка банку в кредитах банківського сектору (валові суми) (у \%) всіх кредитів клієнтам, кредитів юридичним особам, кредитів фізичним особам;

- частка банку в показнику системи (у \%) в загальних активах, в портфелях ОВДП;

- приріст (у \%) загальних активів та валової суми кредитів клієнтам.

9. Залучення коштів клієнтів державними банками порівняно з вибіркою банків та банківською системою загалом:

- приріст коштів клієнтів (у \%);
- приріст коштів юридичних осіб (у \%);

- приріст коштів фізичних осіб (у \%);

- частка в коштах клієнтів системи (у \%);

- частка в коштах фізичних осіб (у \%);

- частка в коштах юридичних осіб (у \%).

10. Продуктивність мережі філіалів вибірки банків за обсягами залучення коштів клієнтів в банках 3 державною часткою, банках іноземних банківських груп, банках з приватним капіталом:

- загальна кількість філіалів;

- кошти юридичних осіб на один філіал (у тис. грн.);

- кошти фізичних осіб на один філіал (у тис. грн.).

11. Бізнес-доходи банків з державною часткою, банках іноземних банківських груп та банках з приватним капіталом:

- бізнес-дохід (у тис. грн.), який включає в себе чистий процентний дохід, чистий комісійний дохід та результат від купівлі-обміну валюти (прибутки від курсової різниці, коливання вартості цінних паперів та формування/розформування резервів визначаються як непередбачені доходи);

- операційний дохід (у тис. грн.);

- відношення бізнес-доходу до операційного доходу $($ у \%);

- частка в бізнес-доходах (у \%) чистого процентного доходу та чистого комісійного доходу.

12. Показники ефективності бізнесу державних банків порівняно з вибіркою банків і банківською системою загалом:

- рентабельність активів (ROA) (у \%), має бути не нижчою, ніж рівень інфляції;

- рентабельність власного капіталу (ROE) (у \%), має бути не нижчою, ніж мінімальна дохідність для інвесторів;

- відношення операційного доходу до активів (у \%), має бути мінімум $10 \%$;

- ефективність бізнесу (cost/income ratio) (у \%), має бути максимум 55\%.

13. Коригування фінансового результату банків на формування або розформування резервів під кредитні ризики:

- відрахування до резервів (у млн грн.);

- прибуток/збиток до оподаткування (у млн грн.);

- вплив відрахувань до резервів на фінансовий результат до оподаткування (у млн грн.).

На підставі проведеного аналізу Г.П. Бортніков [7] також доходить висновку щодо універсальності бізнес-моделей державних банків, проте розподіляє всі банки за такими бізнес-моделями, як: роздрібно-корпоративна (РК), корпоративно-роздрібна (КР), корпоративна (К), роздрібна (Р). На думку автора методики, АТ КБ “Приватбанк” має роздрібно-корпоративну бізнес-модель, АТ “Ощадбанк” - корпоративно-роздрібну, АТ “Укрексімбанк” - корпоративну, АБ “Укргазбанк” - корпоративно-роздрібну, ПАТ “Розрахунковий центр" - корпоративну.

Отриманий автором висновок потребує особливого коментаря. На наш погляд, усі державні банки України 
мають підвищену частку активів у державних цінних паперах і є залежними від надходжень за розміщеними коштами у ОВДП. Наприклад, станом на 01.05.2020 p. у структурі активів АТ КБ “Приватбанк” цінні папери займають $32 \%$, у АТ “Ощадбанк” - 28\%, у АТ “Укрексімбанк” - 19\%, у АБ “Укргазбанк” - 40\%. Відповідна структура активів впливає й на джерела надходжень банків. За 4 місяці 2020 року АТ КБ “Приватбанк” отримав прибуток у сумі 17,3 млрд грн. При цьому головним джерелом стали не традиційні операції банків iз роздрібно-корпоративною бізнес-моделлю, а надходження за розміщеними цінними паперами. Чистий процентний дохід становив лише 7 млрд грн., а комісійний - 5,4 млрд грн.

Ще у одному дослідженні науковці Г.О. Панасенко та Г.П. Бортніков [8] провели аналіз бізнес-моделей українських банків залежно від моделі залучення ними коштів від клієнтів. Для аналізу були використали дані офіційної звітності банків, яка оприлюднюється на сайті НБУ, за період 3 початку 2014 року та станом на 01.07.2016. Як основні показники для визначення бізнес-моделей були використані такі:

1. Частка коштів фізичних осіб у зобов'язаннях банків (значення показника має бути менше 50\%).

2. Частка строкових депозитів у коштах фізичних осіб (значення показника має бути менше 70\%).

3. Частка коштів на вимогу в коштах фізичних осіб (значення показника має бути більше 60\%).

4. Відношення кредитів клієнтам до коштів клієнтів (прийнятним є значення показника на рівні 120\%).

5. Частка коштів в іноземній валюті (значення показника має бути менше $30 \%$ ).

6. Динаміка мережі філіалів (прийнятним є приріст не більше 10\% або зменшення не більш ніж на 5\%).

На основі проведеного аналізу дослідники виділили п’ять кластерів (бізнес-моделей) банків, виходячи 3 характеру залучення ними коштів клієнтів.

У першому кластері об'єдналися банки із дуже значною залежністю від коштів, які залучаються від клієнтів (більше 90\%). До кластеру належать як великі, так і середні й малі банки, при цьому близько 50\% банків кластеру демонструють низькі показники рентабельності та навіть збитки за результатами роботи.

У другому кластері об'єдналися банки із високою залежністю від коштів, які залучаються від клієнтів (від 70\% до 90\%). До кластеру належать як великі, так і середні й малі банки, при цьому близько $25 \%$ банків кластеру демонструють низькі показники рентабельності та навіть збитки за результатами роботи.

У третьому кластері об'єдналися банки із дуже низькою залежністю від коштів, які залучаються від клієнтів (до 30\%). До кластеру належать іноземні та малі банки, при цьому понад 50\% банків кластеру демонструють низькі показники рентабельності та навіть збитки за результатами роботи.

У четвертому кластері об'єдналися банки із низьким рівнем залежності від коштів, які залучаються від клієнтів (від 30\% до 50\%). До кластеру належать як іноземні, так і державні й малі банки, при цьому 50\% банків кластеру демонструють низькі показники рентабельності та навіть збитки за результатами роботи.

I, нарешті, у п’ятому кластері об'єдналися банки із високою залежністю від коштів, які залучаються від клієнтів (від 70\% до 90\%). До кластеру належать як великі, так і середні й малі банки, при цьому більше 30\% банків кластеру демонструють низькі показники рентабельності та навіть збитки за результатами роботи.

На нашу думку, зазначена методика охоплює лише одну з багатьох сфер бізнесу банків - залучення коштів клієнтів, а тому може розглядатися лише як частина комплексної методики визначення бізнес-моделей банків.

Дослідники О.В. Литвинюк та М.О. Карпов [9] провели кластерний аналіз 12 системних українських банків, який грунтується на кількісній оцінці показників прибутковості та ризику. Для визначення бізнес-моделей дослідники запропонували такі показники:

1. Результативний показник бізнес-моделі - чиста процентна маржа банку (у \%).

2. Кількісні показники бізнес-моделей, що характеризують ризики фінансової діяльності:

- частка власного капіталу на покриття ризиків (у \%);

- кредитна активність банків (у \%);

- стабільність ресурсної бази (у \%);

- розподіл кредитного портфеля (у \%);

- нормативи ліквідності (у \%);

- віддача власного капіталу (у \%);

- достатність капіталу (у \%).

Науковці визначили три бізнес-моделі для українських системних банків.

Універсальна бізнес-модель характеризується тим, що банки, які до неї належать, виконують всі види банківських операцій на ринку, завдяки чому ризики диверсифікуються. Така модель, на думку авторів методики, $є$ найбільш привабливою та ефективною.

Роздрібна бізнес-модель характеризується тим, що банки, які до неї належать, орієнтовані на надання короткострокових споживчих кредитів фізичним особам, тобто мають розвинене роздрібне кредитування.

Корпоративна бізнес-модель характеризується тим, що банки, які до неї належать, оріснтовані як на корпоративний, так і на роздрібний бізнес, а також мають значні обсяги комісійних доходів завдяки значній кількості та різноманітності виконуваних операцій на ринку. На думку авторів методики, банки із корпоративною бізнес-моделлю належать до найбільших системних банків та користуються значним рівнем довіри серед населення, оскільки акцентується увага на захисті коштів вкладників та кредиторів державою у разі значних соціально-економічних коливань.

На наш погляд, основними недоліками такої методики є неврахування структури доходів та витрат банку, якості його активів та валютних ризиків. Крім цього, обрання у якості результуючого параметра показник чистої процентної маржі банку переносить акцент лише на кредитування та залучення депозитних 
коштів, при цьому некредитні та інвестиційні операції не прийняті до уваги.

Н.М. Пантєлєєва [10] у своєму дослідження здійснила аналіз найбільших іноземних та російських фінансових корпорацій, фінансових груп та банків. На думку дослідниці, можна виділити такі бізнес-моделі європейських банків, як: роздрібна, інвестиційна, універсальна. Основними показниками, на підставі яких були зроблені висновки, стали: депозити, торгові активи, деривативи.

Для аналізу бізнес-моделей російських банків Н.М. Пантєлєєва [10] використала таку систему показників, як: структура банківських операцій, рівень фінансового посередництва, рівень достатності капіталу та ліквідності, показник якості кредитного портфеля. Результати дослідження дали змогу сформувати висновок щодо універсальності бізнес-моделей російських банків.

А.С. Стадник [11] у своїй роботі провів грунтовне дослідження профілів ризику українських банків, виходячи з вибраної ними бізнес-моделі та використовуючи інструменти кластерного аналізу. У якості основних змінних для проведення кластеризації та визначення бізнес-моделей автором методики було вирано такі показники, як:

1. Частка кредитів в активах та адекватність капіталу, які характеризують рівень кредитного ризику.

2. Частка ліквідних активів у активах та частка цінних паперів у активах, які характеризують рівень ризику ліквідності.

3. Частка активів в іноземній валюті та частка зобов'язань в іноземній валюті, які характеризують рівень валютного ризику.

4. Частка процентних доходів у доходах та частка процентних витрат у витратах, які характеризують рівень процентного ризику.

Проведений аналіз дозволив автору методики визначити 5 кластерів, які характеризують основні ризикпрофілі та бізнес-моделі українських банків.

Характерними ознаками банків, які увійшли до першого кластеру, стали наявність значної частки процентної складової у складі доходів та витрат, достатній рівень ліквідності, незначна частка кредитних операцій при достатньому рівні адекватності капіталу, незначна частка активів та зобов'язань в іноземній валюті. Профіль ризику таких банків автор методики визначає як «процентний».

Характерними ознаками банків, які увійшли до другого кластеру, стали високий рівень адекватності капіталу, дуже незначна частка кредитних операцій, при значному обсязі цінних паперів в складі активів, незначні обсяги активів та зобов'язань в іноземній валюті та значна частка процентних доходів у загальному обсязі доходів банку. Профіль ризику таких банків автор методики також визначає як «процентний», проте, на його думку, у цей кластер об'єднуються саме мікробанки.

Характерними ознаками банків, які увійшли до третього кластеру, стали незначний обсяг активів та зобов’язань в іноземній валюті (50\% банків кластеру банки з іноземним капіталом), значна частка процентного складника у складі доходів та витрат банку, інші показники мають відносно середнє значення. Профіль ризику таких банків автор методики також визначає як «валютно-процентний».

Для банків, які увійшли до четвертого кластеру, характерними ознаками є значна частка процентного складника у складі доходів та витрат банку, значний обсяг кредитних операцій та значний ризик ліквідності. Профіль ризику таких банків автор методики також визначає як «кредитно-процентний із високим рівнем ризику ліквідності».

Для банків, які увійшли до п’ятого кластеру, характерними є середні значення за кожним із показників ризику. Відповідно до цього, автор методики визначив ризик-профіль таких банків як «зважено-поміркований».

На нашу думку, показники, які вибрані для визначення бізнес-моделей сфокусовані лише навколо відповідних ризиків, що притаманні банківській діяльності, та повною мірою не відображають їі особливості.

Дослідники В. Рашкован та Д. Покідін [12] у своїй роботі провели аналіз бізнес-моделей банків, використовуючи методи кластеризації, та оцінку їхньої схильності до різного роду ризиків. Основним методологічними інструментом, що використовувався, були самоорганізаційні карти Кохонена.

Слід звернути увагу, що вперше кластеризацію банківської системи України, виходячи із структурнофункціональних характеристик банків та використовуючи самоорганізаційні карти Кохонена (SOM), провела у своїх дослідженнях О.П. Заруцька [13].

Основними змінними, які визначають бізнес-моделі, В. Рашкован та Д. Покідін Д. [12] вибрали такі:

1. Активи/філії (у гривнях) - співвідношення між вартістю активів та кількістю філій, яку має банк. Показник характеризує інтенсивність використання банком мережі філій для ведення діяльності.

2. Середній термін погашення кредитів (у роках) співвідношення між залишками кредитів на певну дату та терміном їх погашення.

3. Середній розмір кредитів (у тисячах гривень) - співвідношення між загальним обсягом кредитного портфелю та кількістю укладених кредитних договорів.

4. Частка власного капіталу та субординованого боргу. Показник визначає частку запозичених коштів.

5. Частка роздрібних кредитів - співвідношення між кредитами, що надані фізичним особам (роздрібні кредити), та обсягом активів, які приносять дохід.

6. Частка роздрібних депозитів - співвідношення між депозитами, що залучені від фізичних осіб (роздрібне фінансування), та загальним обсягом зобов'язань без врахування субординованого боргу. Показник визначає частку роздрібного фінансування в загальних зобов'язаннях банку та вказує на те, якою мірою банк покладається на фізичних осіб у фінансуванні своїх операцій. 
7. Частка кредитів - співвідношення між обсягом кредитів, без врахування міжбанківських, та загальним обсягом активів. Показник вказує на схильність банку до реалізації типових та традиційних банківських продуктів.

На основі проведеного аналізу, дослідники визначили шість основних бізнес-моделей, які мають місце у банківській системі країни.

Бізнес-модель «Домогосподарства-корпорації». Визначальними особливостями цієї моделі бізнесу науковці зазначили наявність малої частки кредитів, наданих фізичним особам, тобто роздрібних кредитів, але велика частка кредитів, наданих юридичним особам, тобто переважне корпоративне кредитування, крім цього, спостерігається великий обсяг депозитів фізичних осіб. На думку вторів методии, банки з такою бізнес-моделлю, як правило фінансують домогосподарства-корпорації, крім цього присутній ризик кредитування пов'язаних з банком осіб.

«Роздрібна бізнес-модель» характеризується великим обсягом кредитів фізичним особам, а також великим обсягом депозитів, які також залучені від фізичних осіб.

«Універсальна бізнес-модель», на думку авторів методики, поєднує у собі кредитні та некредитні продукти та послуги. Банки із такою бізнес-моделлю здійснюють як роздрібне, так й корпоративне кредитування, а також мають значну частку (але меншу, ніж в «Роздрібній бізнес-моделі» та бізнес-моделі «Домогосподарства-корпорації») депозитів, що залучаються від фізичних осіб.

Банки із «корпоративною» моделлю бізнесу обслуговують лише корпоративний сегмент, при цьому кредитування має короткостроковий характер, а роздрібні кредити та депозити відсутні. Також відсутні філії.

Банки 3 «інвестиційною бізнес-моделлю» мають найменший обсяг кредитних операцій та найбільша некредитних.

I останнє: «заморожені/невизначені банки» мають високо диференційовану структуру активів та зобов'язань, значний обсяг власного капіталу та субординованого боргу, при цьому депозити не залучаються. Як правило, до цієї бізнес-моделі потрапляють новостворені банки, неактивні банки або ж банки, які не визначилися щодо бізнес-моделі чи провадять нетрадиційну діяльність.

Аналіз підходів до визначення бізнес-моделей банків показав, що всі вони мають багато спільних рис, насамперед методики базуються на показниках фінансової звітності банків та аналізі їх змін із плином часу. Крім цього, у якості ключового інструменту для визначення бізнес-моделей обрано саме кластерний аналіз, який дозволяє під час групування одночасно врахувавати усі змінні та групувальні ознаки.

Водночас головним недоліком існуючих підходів, на наш погляд, є недостатня орієнтація на ключові ризики банківської системи у конкретний період розвитку. Для системного охоплення характеристик банків необхідно розширити перелік показників, що використовуються під час формування кластерів. Для формування системи показників можна скористатися методикою Національного банку України.

У межах реалізації методики SREP-аналі, НБУ [14] здійснює аналіз та оцінку бізнес-моделей банків, що включає в себе проведення оцінки життєздатності бізнес-моделі (viability), тобто здатності генерувати прийнятний рівень доходів протягом наступних 12 місяців, 3 урахуванням показників ефективності, відповідності структури фінансування банку його бізнес-моделі та ризик-апетиту (або схильності до ризику), а також проведення оцінки стійкості стратегії банку (sustainability), тобто здатності генерувати прийнятний рівень доходів протягом щонайменше наступних трьох років згідно iз затвердженою стратегією банку та бізнес-планом (у тому числі з урахуванням виконання стратегії банку в минулому).

У якості основних інструментів для проведення оцінки бізнес-моделі банку використовується система маркерів та балів, що дозволяють оцінити прогнозні показники та правдоподібність прийнятих припущень щодо майбутнього бізнес-середовища банку.

Схематично визначення бізнес-моделі банку НБУ можна визначити як таку послідовність дій:

1. Заповнення банком шаблону та надання його НБУ.

2. Перевірка НБУ повноти та достовірності даних, в тому числі й на основі даних статистичної звітності, та, за необхідності, уточнення даних.

3. Моделювання прогнозних показників банку та оцінка правдоподібності припущень, в тому числі й 3 урахуванням макроекономічних показників. Можливе уточнення початково закладених припущень.

4. Здійснення коригування нереалістичнх припущень за їх наявності.

5. Проведення аналізу показників, експертна та бальна оцінка.

6. Формулювання висновків щодо життєздатності та стійкості бізнес-моделі (оцінка від 1 до 4), надання коментарів, проведення порівнянь, надання рекомендацій.

Проведення оцінки бізнес-моделі банку відбувається у вигляді отримання узагальнюючої бальної оцінки (від 1 до 4) з використанням набору якісних та кількісних показників, з урахуванням можливих додаткових факторів впливу.

Система показників, які використовуються НБУ для оцінки бізнес-моделей банків наведені у таблиці (табл. 1).

Після визначення бальної оцінки бізнес-моделі за якісними та кількісними показниками, а також використання «Матриці визначення оцінки життєздатності та стійкості бізнес моделі», урахування додаткових факторів впливу, отримується загальна фінальна оцінка. Оцінка бізнес-моделей банків здійснюється за всіма банками системи щорічно за допомогою VS model та може відбуватися із поглибленим аналізом або ж за спрощеною оцінкою. 
Система показників НБУ для оцінки бізнес-моделей банків

\begin{tabular}{|c|c|c|}
\hline $\begin{array}{l}\text { № } \\
\text { 3/II }\end{array}$ & Показники & \begin{tabular}{|c|} 
Вага групи / \\
показника \\
\end{tabular} \\
\hline 1. & \multicolumn{2}{|l|}{ Кількісні показники } \\
\hline 1.1. & Група показників прибутковість /ризики & 0,6 \\
\hline 1.1 .1 & Співвідношення операційних витрат до операційних доходів & 0,40 \\
\hline 1.1 .2 & Чиста процентна маржа з врахуванням витрат на резерви & 0,25 \\
\hline 1.1 .3 & Покриття витрат на персонал непроцентними доходами & 0,05 \\
\hline 1.1 .4 & Співвідношення чистого комісійного доходу та чистих активів & 0,05 \\
\hline 1.1 .5 & Рентабельність власного капіталу & 0,10 \\
\hline 1.1 .6 & Достатність основного капіталу & 0,10 \\
\hline 1.1 .7 & Покриття кредитів, наданих клієнтам, залученими коштами клієнтів & 0,025 \\
\hline 1.1 .8 & Співвідношення непокритих кредитним ризиком проблемних активів до регулятивного капіталу & 0,025 \\
\hline 1.2. & Група показників концентрації & 0,3 \\
\hline 1.2 .1 & Концентрація ТОП 5 позичальників /групп пов'язаних позичальників & 0,40 \\
\hline 1.2 .2 & Концентрація ТОП 5 кредиторів & 0,30 \\
\hline 1.2 .3 & Залежність від коштів інших банків та міжнародних організацій & 0,30 \\
\hline 1.3. & Група показників конкурентоспроможності & 0,1 \\
\hline 1.3 .1 & Співвідношення операційних та капітальних витрат на IT до загального обсягу активів & 0,4 \\
\hline 1.3 .2 & Співвідношення витрат на маркетинг та спонсорство до загального обсягу активів & 0,3 \\
\hline 1.3 .3 & Співвідношення витрат на персонал до загальної кількості персоналу & 0,3 \\
\hline 2. & \multicolumn{2}{|l|}{ Якісні показники } \\
\hline 2.1. & \begin{tabular}{|l|} 
Показник досягнення планових показників (передбачених стратегічним планом з врахуванням виконання \\
інших фінансових планів, програм капіталізації, планів реструктуризації наданими банком до НБУ)
\end{tabular} & 0,25 \\
\hline 2.2. & $\begin{array}{l}\text { Показник реалістичності розвитку, який характеризує потенційні можливості банку для досягнення } \\
\text { прогнозних показників, передбачених стратегією банку, бізнес-планом та іншими фінансовими } \\
\text { планами. Достатність рівня ліквідності та доступність ринків для залучення фінансування. }\end{array}$ & 0,20 \\
\hline 2.3 . & $\begin{array}{l}\text { Показник репутаційного ризику (якість репутації банку, його власників істотної участі та керівників } \\
\text { на ринку, від репутації яких залежить успішність реалізації бізнес-моделі) }\end{array}$ & 0,15 \\
\hline 2.4 . & $\begin{array}{l}\text { Показник дотримання пруденційнихвимог (дотримання встановлених економічних нормативів та } \\
\text { нормативів і порядку обов'язкового резервування коштів на кореспондентському рахунку протягом } \\
\text { останніх шести місяців) }\end{array}$ & 0,15 \\
\hline 2.5 & $\begin{array}{l}\text { Показник оцінки ризику операцій з пов'язаними особами (комплексна оцінка (бал } 1-4) \text { щодо оцінки } \\
\text { ризику операцій з пов’язаними з банком особами) }\end{array}$ & 0,25 \\
\hline
\end{tabular}

У межах SREP-аналізу НБУ пропонує таку класифікацію бізнес-моделей банків [14]:

1. Універсальна бізнес-модель. Характеризується суттєвою часткою операцій з юридичними, фізичними особами, міжбанківських операцій та операціями 3 іншими учасниками фінансового ринку у структурі активів та зобов'язань.

2. Роздрібна бізнес-модель. Характеризується суттєвою часткою операцій з фізичними особами у структурі активів та зобов'язань.

3. Корпоративна бізнес-модель. Характеризується суттєвою часткою кредитних операцій з юридичними особами у структурі активів та залучених коштів від юридичних осіб у структурі зобов'язань.

4. Корпоративна модель бізнесу з роздрібним фінансуванням. Характеризується суттєвою часткою кредитних операцій з юридичними особами у структурі активів та залучених коштів від фізичних осіб у структурі зобов'язань.

5. Бізнес-модель обмеженого кредитного посередництва. Характеризується незначною часткою кредитів, наданих юридичним та фізичним особам, яка ста- новить не більше $30 \%$, левова частка кредитів надана обмеженому колу осіб або ж активні операції профінансовано власними коштами банку.

Слід зазначити, що проведений аналіз існуючих методик визначення та оцінки бізнес-моделей банків в Україні, в тому числі й методики, яка застосовується НБУ, дав змогу дійти висновку щодо необхідності їх удосконалення та розвитку. На нашу думку, ключовими недоліками зазначених методик $\epsilon$ неврахування валютних ризиків, а також використання набору показників, які не повною мірою розкривають суттєві структурно-функціональні характеристики банків та притаманні їм ризики.

На базі системи показників НБУ автором запропоновано власний набір змінних, які дозволять сутнісно розширити та розвинути існуючий алгоритм оцінки (табл. 2).

Коефіцієнти, що зазначені у таблиці 2, дозволяють отримати чітке уявлення про структуру активів, пасивів, доходів та витрат банку, а також визначити ступінь кредитного, валютного ризику та ризику ліквідності. Важливим у методиці є використання як кількісних коефіцієнтів, що запропоновані НБУ, так й інших індикаторів, що таким чином розширює межі аналізу. Таким чином, 
Основні коефіціснти-індикатори для визначення бізнес-моделей банків

\begin{tabular}{|c|c|c|}
\hline $\begin{array}{l}\text { № } \\
\text { 3/II }\end{array}$ & Позначення & Характеристика \\
\hline 1 & ЧАн.в./ЧАс & Частка чистих активів банку в національній валюті у чистих активах системи \\
\hline 2 & Чаi.в./ЧАс & Частка чистих активів банку в іноземній валюті у чистих активах системи \\
\hline 3 & ЛАн.в./ЧА & Частка ліквідних активів банку в національній валюті у чистих активах банку \\
\hline 4 & ЛАі.в./ЧА & Частка ліквідних активів банку в іноземній валюті у чистих активах банку \\
\hline 5 & КрБн.в./ЧА & Частка коштів в інших банках в національній валюті у чистих активах банку \\
\hline 6 & КрБі.в./ЧА & Частка коштів в іших банках в іноземній валюті у чистих активах банку \\
\hline 7 & КрЮОн.в./ЧА & Частка кредитів юридичних осіб в національній валюті у чистих активах банку \\
\hline 8 & КрЮОі.в./ЧА & Частка кредитів юридичних осіб в іноземній валюті у чистих активах банку \\
\hline 9 & КрФОн.в./ЧА & Частка кредитів фізичних осіб в національній валюті у чистих активах банку \\
\hline 10 & КрФОі.в./ЧА & Частка кредитів фізичних осіб в іноземній валюті у чистих активах банку \\
\hline 11 & ОВДПн.в./ЧА & Частка ОВДП в національній валюті у чистих активах банку \\
\hline 12 & ОВДПі.в./ЧА & Частка ОВДП в іноземній валюті у чистих активах банку \\
\hline 13 & $\mathrm{H} 7$ & Норматив максимального розміру кредитного ризику на одного контрагента \\
\hline 14 & $\mathrm{H} 8$ & Норматив великих кредитних ризиків \\
\hline 15 & Рез.АО/Заг.А & Частка відрахувань до резервів за активними операціями банку у загальних активах банку (якість активів) \\
\hline 16 & КоЮОн.в./Заг.3 & Частка коштів, залучених від юридичних осіб в національній валюті, у загальних зобов'язаннях банку \\
\hline 17 & КоЮОі.в./Заг.3 & Частка коштів, залучених від юридичних осіб в іноземній валюті, у загальних зобов'язаннях банку \\
\hline 18 & КоФОн.в./Заг.3 & Частка коштів, залучених від фізичних осіб в національній валюті, у загальних зобов'язаннях банку \\
\hline 19 & КоФОі.в./Заг.3 & Частка коштів, залучених від фізичних осіб в іноземній валюті, у загальних зобов'язаннях банку \\
\hline 20 & КоБн.в./Заг.3 & Частка залучених коштів від інших банків в національній валюті у загальних зобов’язаннях банку \\
\hline 21 & КоБі.в./Заг.3 & Частка залучених коштів від інших банків в іноземній валюті, у загальних зобов’язаннях банку \\
\hline 22 & КрКн.в./КоКн.в. & $\begin{array}{l}\text { Покриття кредитів, наданих клієнтам в національній валюті, залученими коштами клієнтів в } \\
\text { національній валюті }\end{array}$ \\
\hline 23 & КрКі.в./КоКі.в. & $\begin{array}{l}\text { Покриття кредитів, наданих клієнтам в іноземній валюті, залученими коштами клієнтів в іноземній } \\
\text { валюті }\end{array}$ \\
\hline 24 & РК/ЧА & Регулятивний капітал банку, зважений на чисті активи банку \\
\hline 25 & BM/ЧA & Частка витрат банку на маркетинг у чистих активах банку \\
\hline 26 & ОВ/ЧА & Частка операційних витрат банку у чистих активах банку \\
\hline 27 & ОД/ЧА & Частка операційних доходів банку у чистих активах банку \\
\hline 28 & НД/ЧА & Частка непроцентних доходів банку у чистих активах банку \\
\hline 29 & ЧПМ & Чиста процентна маржа \\
\hline 30 & ВЗзалуч.К & Вартість залучених коштів банком \\
\hline 31 & ДРозміщ.К & Дохідність розміщених коштів банком \\
\hline 32 & ВРез./ЧА & Частка відрахувань до резервів у чистих активах банку \\
\hline 33 & PA & Рентабельність активів банку \\
\hline
\end{tabular}

запропонований підхід дозволяє поєднати метод СФГБ та вимоги НБУ щодо визначення бізнес-моделей банків.

Проте слід розуміти, що така система показників не може бути сталою, а має змінюватися з урахуванням змін зовнішнього та внутрішнього середовища банківської системи країни та циклічності розвитку економіки.

Процес визначення бізнес-моделей охоплює всю банківську систему, передбачає використання великих масивів фінансової інформації та вимагає одночасного урахування значної кількості змінних факторів.

Одним із методів, який, на нашу думку, дозволяє вирішити це завдання, та визначити бізнес-модель банку, а також пов'язаний із нею профіль-ризику, є використання нейронних мереж, зокрема самоорганізуючих карт Кохонена (СОК), тема яких докладно була розглянута у монографії О.П. Заруцької «Банківський нагляд 3 використання структурно-функціонального аналізу: теорія, світовий і вітчизняний досвід» [13].
Формування самоорганізуючих карт Кохонена (СОК) можливо здійснити за допомогою програмного комплексу Viscovery SOMine. Визначення кількості кластерів та їх формування здійснюється програмним комплексом самостійно, на підставі сформованої бази даних основних кількісних показників діяльності банків (коефіцієнтів-індикаторів). Кожний банк на карті має відповідне місце (точку), яка визначається виходячи із значень його основних коефіцієнтів-індикаторів та значень сусідніх банків. Точка карти - місце розташування одного або кількох банків у період дослідження.

На нашу думку, саме такий підхід дозволяє згрупувати банки таким чином, щоб охопити їхні основні сутнісні структурно-функціональні характеристики, визначити на підставі цього модель бізнесу, а також притаманний іï профіль ризику, що, в свою чергу, дозволяє застосовувати диференційований підхід до нагляду та регулювання діяльності банків. 
Крім цього, практичне використання зазначено методу для проведення аналізу бізнес-моделей банків [15-19], вказує на те, що сформовані таким чином групи зберігають своє наповнення та однорідність протягом тривалого проміжку часу. Натомість, можлива їх зміна пов'язана із впливом інших об'єктивних чинників, як то зміна стратегії діяльності, що може супроводжуватися й зміною у складі акціонерів банку. Крім цього, поширення кризових явищ в економіці та політично-економічна нестабільність провокують розширення кластеру проблемних банків. Використання нейронних мереж, а саме самоорганізаційних карт Кохонена, дозволяє спостерігати за зміною положення банків на карті, будувати траєкторію його руху й завдяки цьому попереджувати можливу втрату ними фінансової стійкості за умови наближення до кластеру проблемних банків. А отже, визначення бізнес-моделей банків, виходячи 3 їхніх основних структурно-функціональних характеристик та використовуючи самоорганізаційні карти Кохонена, дасть змогу проводити спостереження за розвитком банку, його групи (кластеру) та всієї банківської системи країни, а також чітко визначати етапи структурних змін та підвищення впливу ризикових факторів.

Висновки. Таким чином, дослідження наявних підходів до визначення бізнес-моделей в Україні дало змогу встановити, що запропоновані методики спираються на показники фінансової звітності банків та використовують інструменти кластерного аналіз. При цьому часовий інтервал дослідження, кількість визначальних характеристик, які залучаються до кластеризації, а також кількість отриманих кластерних груп відрізняються у кожному дослідженні, а інтерпретація отриманих результатів здійснюється на підставі суб'єктивного судження автора. Запропонований нами підхід з використанням нейронних мереж, а саме самоорганізуючих карт Кохонена (СОК), дає змогу охоплювати та структурувати великі масиви даних, об'єднуючи банки таким чином, що до одного кластера потрапляють об'єкти зі схожими структурно-функціональнми характеристиками, а банки із найбільшими відмінностями розташовуються у різних частинах карти. Отримані таким чином бізнес-моделі відображають сутнісні відмінні характеристики банків та дозволяють на цій основі сформувати профіль його ризиків. Крім того, така карта дає змогу візуалізувати отримані результати, що спрощує процес інтерпретації отриманих результатів. Запропонований підхід дозволяє на мікрота макрорівні досліджувати банківську систему країни, оцінювати та порівнювати бізнес-моделі різних банків, а також траєкторію їх можливих змін з плином часу.

\section{Список літератури:}

1. Про внесення зміни до Положення про організацію та проведення інспекційних перевірок : Постанова Правління Національного банку України від 02.05.2018 № 47 / Національний банк України. URL: https://zakon.rada.gov.ua/laws/show/v0047500-18 (дата звернення 26.06.2020).

2. Про затвердження Положення про організацію системи управління ризиками в банках України та банківських групах : Постанова Правління Національного банку України від 11.06.2018 № 64 / Національний банк України. URL: https://zakon.rada.gov.ua/laws/show/v0064500-18 (дата звернення 26.06.2020).

3. Onyshchenko Y. Banking business models in Ukrainian banking system. Baltic Journal of Economic Studies. 2015. Vol. 1. № 2. P. 115-121. DOI: 10.30525/2256-0742/2015-1-2-115-121

4. Онищенко Ю.І., Заяць Е.Л. Теоретичні підходи до визначення дефініції «бізнес-модель банку». Digital and Innovative Economy: Processes, Strategies, Technologies : International Scientific Conference. Kielce, Poland, January 25, 2019. P.101-104.

5. Деркаченко А.В., Худолій Ю.С. Аналіз бізнес-моделей банків України. Облік і фінанси. 2018. № 2. С. $76-83$.

6. Любіч О.О., Бортніков Г.П., Панасенко Г.О. Аналіз бізнес-моделі державних банків в Україні. Фінанси України. 2016. № 10. С. 7-38.

7. Бортніков Г.П. Порівняльний аналіз бізнес-моделі державних банків в Україні. Фінанси Украӥни. 2019. № 1. C. 80-101.

8. Панасенко Г.О., Бортніков Г.П. Модель бізнесу українських банків в залученні коштів клієнтів. Економікоматематичне моделювання сочіально-економічних систем. 2016. № 21. С. 228-254.

9. Литвинюк, О.В., Карпов М.О. Методичні підходи до оцінки бізнес-моделей системних банків України на засадах багатовимірного кластерного аналізу. Глобальні та наизіональні проблеми економіки. 2017. № 17. С. 677-683.

10. Пантєлєєва Н.М. Інноваційні бізнес-моделі банків як відповідь на виклики та наслідки фінансової кризи. Фінансовий простір. 2013. № 3(11). С. 70-76.

11. Стадник А.С. Розвиток концепції мікропруденційного банківського регулювання в Україні на основі запровадження аналізу бізнес-моделей банків. Науковий погляд: економіка та управління. 2017. № 2(58). С. 107-115.

12. Рашкован В., Покідін Д. Кластерний аналіз бізнес-моделей українських банків: застосування нейронних мереж Кохонена. Вісник Національного банку Украӥни. 2016. № 238. С. 13-40.

13. Заруцька О.П. Банківський нагляд з використанням структурно-функціонального аналізу: теорія, світовий і вітчизняний досвід : монографія. Суми : ДВНЗ “УАБС НБУ”, 2013. 379 с.

14. Офіційний сайт Національного банку України : веб-сайт. URL: https://www.bank.gov.ua (дата звернення: 26.06.2020).

15. Заруцька О.П. Рання діагностика втрати фінансової стійкості банків у системі банківського нагляду. Вісник Української академії банківської справи. 2013. № 1. С. 89-93.

16. Васильєва Т., Заруцька О. Розвиток структурно-функціонального підходу до аналізу фінансової стійкості в системі банківського нагляду. Вісник Націіонального банку Украӥни. 2013. № 10. С. 28 -35. 
17. Заруцька О.П. Дослідження виведення українських банків з ринку з використанням структурно-функціонального аналізу. Вісник економічної науки Украӥни. 2016. № 2. С. 73-78.

18. Заруцька О.П., Згонік С.В., Косюга В.В. Структурно-функціональні характеристики банківської системи України та шляхи підвищення ії ефективності. Науковий погляд: економіка та управління. 2017. № 2(58). С. 77-96.

19. Zarutska, O., Pavlova, T., Sinyuk, A., Khmarskiy, V., Pawliszczy, D., \& Kesy, M. (2020). The Innovative Approaches to Estimating Business Models of Modern Banks. Marketing and Management of Innovations, $2,26-43$. DOI: http://doi.org/10.21272/mmi.2020.2-02

\section{References:}

1. Resolution of the Board of the National Bank of Ukraine On Amendments to the Regulations on the Organization and Conduct of Inspections № 47 (2018, May 2). National Bank of Ukraine. Available at: https://zakon.rada.gov.ua/laws/ show/v0047500-18 (accessed 26 June 2020).

2. Resolution of the Board of the National Bank of Ukraine On approval of the Regulations on the organization of risk management system in banks of Ukraine and banking groups № 64 (2018, June 11). National Bank of Ukraine. Available at: https://zakon.rada.gov.ua/laws/show/v0064500-18 (accessed 26 June 2020).

3. Onyshchenko Y. (2015) Banking business models in Ukrainian banking system. Baltic Journal of Economic Studies, vol. 1, no. 2, pp. 115-121. DOI: 10.30525/2256-0742/2015-1-2-115-121

4. Onyshchenko Y.I., Zaiats E.L. (2019) Teoretychni pidkhody do vyznachennia definitsii «biznes-model banku» [Theoretical approaches to defining the definition of "business model of the bank"]. Proceedings of the Digital and Innovative Economy: Processes, Strategies, Technologies : International Scientific Conference. Kielce, Poland, pp. 101-104.

5. Derkachenko A.V., Khudolii Yu.S. (2018) Analiz biznes-modelei bankiv Ukrainy [Analysis of business models of Ukrainian banks]. Oblik i finansy [Accounting and finance], no. 2, pp. 76-83.

6. Liubich O.O., Bortnikov H.P., Panasenko H.O. (2016) Analiz biznes-modeli derzhavnykh bankiv v Ukraini [Analysis of the business model of state-owned banks in Ukraine]. Finansy Ukrainy [Finance of Ukraine], no. 10, pp. 7-38.

7. Bortnikov H.P. (2019) Porivnialnyi analiz biznes-modeli derzhavnykh bankiv v Ukraini [Comparative analysis of the business model of state-owned banks in Ukraine]. Finansy Ukrainy [Finance of Ukraine], no. 1, pp. 80-101.

8. Panasenko H.O., Bortnikov H.P. (2016) Model biznesu ukrainskykh bankiv v zaluchenni koshtiv kliientiv [Business model of Ukrainian banks in attracting clients' funds]. Ekonomiko-matematychne modeliuvannia sotsialno-ekonomichnykh system [Economic-mathematical modeling of socio-economic systems], no. 21, pp. 228-254.

9. Lytvyniuk, O.V., Karpov M.O. (2017) Metodychni pidkhody do otsinky biznes-modelei systemnykh bankiv Ukrainy na zasadakh bahatovymirnoho klasternoho analizu [Methodical approaches to the assessment of business models of systemic banks of Ukraine on the basis of multidimensional cluster analysis]. Hlobalni ta natsionalni problemy ekonomiky [Global and national economic problems], no. 17, pp. 677-683

10. Pantielieieva N.M. (2013) Innovatsiini biznes-modeli bankiv yak vidpovid na vyklyky ta naslidky finansovoi kryzy [Innovative business models of banks as a response to the challenges and consequences of the financial crisis]. Finansovyi prostir [Financial space], no. 3(11), pp. 70-76.

11. Stadnyk A.S. (2017) Rozvytok kontseptsii mikroprudentsiinoho bankivskoho rehuliuvannia v Ukraini na osnovi zaprovadzhennia analizu biznes-modelei bankiv [Development of the concept of microprudential banking regulation in Ukraine based on the introduction of analysis of business models of banks]. Naukovyi pohliad: ekonomika ta upravlinnia [Scientific view: economics and management], no. 2(58), pp. 107-115.

12. Rashkovan V., Pokidin D. (2016) Klasternyi analiz biznes-modelei ukrainskykh bankiv: zastosuvannia neironnykh merezh Kokhonena [Cluster analysis of business models of Ukrainian banks: application of Kohonen neural networks]. Visnyk Natsionalnoho banku Ukrainy [Bulletin of the National Bank of Ukraine], no. 238, pp. 13-40.

13. Zarutska O.P. (2013) Bankivskyi nahliad z vykorystanniam strukturno-funktsionalnoho analizu: teoriia, svitovyi $i$ vitchyznianyi dosvid: Monohrafia. Sumy: State Higher Educational Institution "Ukrainian Academy of Banking of the NBU".

14. Official site of the National Bank of Ukraine. Available at: https://www.bank.gov.ua (accessed 26 June 2020).

15. Zarutska O.P. (2013) Rannia diahnostyka vtraty finansovoi stiikosti bankiv u systemi bankivskoho nahliadu [Early diagnosis of loss of financial stability of banks in the system of banking supervision]. Visnyk Ukrainskoi akademii bankivskoi spravy [Bulletin of the Ukrainian Academy of Banking], no. 1, pp. 89-93.

16. Vasylieva T., Zarutska O. (2013) Rozvytok strukturno-funktsionalnoho pidkhodu do analizu finansovoi stiikosti v systemi bankivskoho nahliadu [Development of structural-functional approach to the analysis of financial stability in the system of banking supervision]. Visnyk Natsionalnoho banku Ukrainy [Bulletin of the National Bank of Ukraine], no. 10, pp. 28-35.

17. Zarutska O.P. (2016) Doslidzhennia vyvedennia ukrainskykh bankiv z rynku z vykorystanniam strukturno-funktsionalnoho analizu [Study of the withdrawal of Ukrainian banks from the market using structural and functional analysis]. Visnyk ekonomichnoi nauky Ukrainy [Bulletin of Economic Science of Ukraine], no. 2, pp. 73-78.

18. Zarutska O.P., Zghonik S.V., Kosiuha V.V. (2017) Strukturno-funktsionalni kharakterystyky bankivskoi systemy Ukrainy ta shliakhy pidvyshchennia yii efektyvnosti [Structural and functional characteristics of the banking system of Ukraine and ways to increase its efficiency]. Naukovyi pohliad: ekonomika ta upravlinnia [Scientific view: economics and management], no. 2(58), pp. 77-96.

19. Zarutska, O., Pavlova, T., Sinyuk, A., Khmarskiy, V., Pawliszczy, D., \& Kesy, M. (2020). The Innovative Approaches to Estimating Business Models of Modern Banks. Marketing and Management of Innovations, no. 2, pp. 26 -43. 